\title{
Influence of Non-commercial Fuel Supply Systems on Small Engine SI Exhaust Emissions in Terms of European Approval Regulations
}

Łukasz Warguła ( $\sim$ lukasz.wargula@put.poznan.pl)

Politechnika Poznanska https://orcid.org/0000-0002-3120-778X

Piotr Lijewski

Politechnika Poznańska

Mateusz Kukla

Politechnika Poznańska

\section{Research Article}

Keywords: small SI engine, exhaust emissions, non-road, fuel injection, LPG, CNG.

Posted Date: August 17th, 2021

DOI: https://doi.org/10.21203/rs.3.rs-481423/v1

License: (c) (i) This work is licensed under a Creative Commons Attribution 4.0 International License.

Read Full License 


\section{Abstract}

The development and operation of road infrastructure requires machines and equipment driven by lowpowered internal combustion engines. The authors of this paper examined five small spark-ignition engines. They used the most popular commercial design on the market, the Lifan GX 390, with a carburettor power system, and another commercial power unit with the most innovative power system, the Honda iGX 390, characterised by an electronically controlled carburettor flap. The remaining three tested constructions are proprietary solutions modernising the design of the Lifan GX 390 engine. The first is the application of an electronic injection and ignition system powered by gasoline, the second and third are systems powered by alternative fuels. Emissions tests were conducted under identical operating conditions on an engine dynamometer coinciding with European Union guidelines (Regulation $2016 / 1628 / \mathrm{EU})$. The results of the tests showed that innovative solutions in most cases reduced $\mathrm{CO}_{1} \mathrm{CO}_{2}$, and $\mathrm{HC}$ emissions while increasing $\mathrm{NO}_{\mathrm{x}}$ compounds.

\section{Introduction}

The dynamic development of road infrastructure and vehicular transport has undeniable benefits related to economic development (Liu and Chao 2020; Said and Hammami 2017) and the possibility to increase the mobility of people (Meekan et al. 2017) and the movement of goods (Gnap et al. 2019). However, this development is characterised by several negative impacts (Yu et al., 2013) e.g. an increase in air pollution (Ehrenberger et al. 2021; Cepeda et al. 2017; Colvile et al. 2001) and a reduction of natural green areas (Ren et al. 2019) and residential areas (Lin et al. 2015) at the expense of transport infrastructure sprawl.

There is a perceived link between human health, green spaces and pollution from transport (Nieuwenhuijsen 2018). Research is being conducted on the impact of air pollution on people's activity satisfaction, this research clearly indicates the need to improve air quality in urban areas (Ma et al. 2020). The problem is well known, and one of the countermeasures is the introduction of increasingly stringent standards for toxic emissions from vehicles and machinery on a global level. Legislators distinguish groups of machines and vehicles for which acceptable limits of pollutant emissions from their propulsion engines are set, e.g. car and light truck (Regulation 715/2007 (Euro 5/6; Lijewski et al 2020; Ziółkowski et al. 2019), heavy-duty truck and bus (Regulation 595/2009; Rymaniak 2018; Merkisz et al. 2012b), heavyduty vechicles (Regulation (EU) 2019/1242; Yasar et al. 2013) and non-road machinery and vehicles (Directive 97/68/EC; Rymaniak et al. 2020; Kamińska et al. 2019). The last group of machines can be used during the construction and operation of road infrastructure and thus the emissions they generate can be linked to transport. Of the above-mentioned groups affected by the permissible limits of pollutant emissions in the European Union, non-road machinery and vehicles have been characterised by different directives since 2002 depending on the type of internal combustion engine used (compression-ignition $\mathrm{Cl}$ engines or spark-ignition SI engines). The authors in the following study SI engines with a power output not exceeding 19 kW, which are called small engines by the legislators (Regulation 2016/1628/EU). These regulations are characterised by relatively liberal emission limit requirements relative to, for example, motor vehicles (Waluś et al. 2018). This translates into low technical sophistication of the fuel 
supply systems of these engines (Warguła et al. 2018b).This is indicated by commercially available engine designs equipped with carburetor power systems (Warguła et al. 2018a), the use of which was abandoned in automotive vehicles as early as the 1990s. Among other things, they were withdrawn from widespread use in motor vehicles through stringent limits on allowable emissions that carburettor systems could not meet.

The main problem in the construction of fuel supply systems for SI small engine is the necessity of low weight of the whole construction, limited space for the engine and low cost of construction. One of the many problems of using modern injection systems in small engines is the lack of space for an energy generator (e.g. alternator) necessary to power the controller, sensors and actuators used in modern injection systems. Researchers around the world are studying the development of these drive units towards the use of innovative injection systems; mainly indirect injection into the intake manifold with electronic control (Niinikoski et al. 2016) or direct injection (Darzi et al. 2018; Andwari et al. 2018; Tartakovsky et al. 2015). Another direction of development of the described propulsion systems is to change the used fuel or alternative fuel admixtures (alternative fuel within the meaning of the European Union Directive (2014/94/EU), as it is an alternative for energy sources derived from crude oil (EU Directive 2014/94/EU) with respect to classical fuels i.e. gasoline to e.g. ethanol (Ribeiro et al. 2018; Schirmer et al. 2017; Lin et al. 2010), methanol (Ravi et al. 2021; Tartakovsky et al. 2015; Celik et al. 2011; Arapatsakos et al. 2003), LPG (bin Mohd Zain et al 2019; Sabariah et al. 2018; Sulaiman et. al. 2013; Li et al. 2003), CNG (Subramanian 2011; Mikulski et. al. 2015), biogas (lyer 2020; Homdoung et. al. 2015; Surata et al. 2014). Other studies deal with design changes, e.g., valvetrain (Fontana and Galloni 2009) piston design (lyer 2020) or intake manifold (Wahono et al. 2019). The main reason for developmental, simulation, experimental or real-world research is the aim to reduce air pollutant emissions and fuel consumption.

The problem of air pollution generated from these types of engines is important as these drives are applied in machinery used in the construction or maintenance of road infrastructure and very often the operator is in direct contact with the exhaust gases. Examples of such machinery are shown in Figure A.1 and include equipment used in construction and renovation such as circular saws, concrete trowels, rammers, soil drills or equipment used for cleaning and clearing snow from pavements. Another group is road marking machinery for painting road lanes. Another group is machinery related to the maintenance of green infrastructure in the lane area, e.g. combustion scythes, chain saws and wood chippers. Demand for the last group will increase as the benefits of roadside trees are increasingly recognised. Roadside trees reduce the spread of road noise, absorb fine particles (Ozdemir 2019), harmful exhaust compounds from the air (Lahothi et al. 2020; Amorim et al. 2013) and de-icing salts from the soil (Ju et al. 2020; Gałuszka et al. 2011). Studies of metal concentrations in tree rings in industrial and roadside areas confirm the pollutant absorption capacity (Kim et al. 2020). According to the public, residents of large cities appreciate the ecosystem properties of trees and other vegetation elements of roadside infrastructure. Even wild urban roadside vegetation has received high appreciation, although planted and maintained vegetation is preferred. Since many cities lack public green areas, enhancing cultivated and wild roadside vegetation can help provide ecosystem services in areas where people move and live 
nearby (Weber et al. 2014). Another benefit of roadside trees is the protection of pedestrians, vehicles and roads from intense sunlight. In addition to thermal comfort for pedestrians, walking on urban roads surrounded by trees has the potential to significantly reduce negative psychological states such as tension, fatigue, disorientation and anxiety compared to roads without them. Researchers indicate that urban roadside trees are a source of stress relief and improved mental health for urban residents (Elsadek et al. 2019). Roadside studies in tropical areas have shown that trees with relatively large crowns reduced the mean radiant temperature (Tmrt) by $35 \%$ and the physiological equivalent temperature (PET) by $25 \%$ (Zaki et al. 2020). Contributing to improving the microclimate in the road infrastructure area by improving vehicle cooling and reducing heat build-up and improving pedestrian comfort. A final benefit is reducing the possibility of sun glare when moving on roads (Redweik et al. 2019). The disadvantages are the dangers associated with road collisions and damage to trees during adverse weather conditions. The average percentage of accidents, injured persons and fatalities related to collisions with a tree in Poland between 2003 and 2015 among the total road accidents, is at 6\%, 6\% and 14\% (Rosłon-Szeryńska et al. 2019). They indicate that measures should be taken to reduce the risk of a road accident in a wooded area, as such events are characterised by a relatively high probability of a fatal event. According to the authors, it can be assumed that the demand for wood chipping machines in transport-related industries will increase due to the handling of trees in roadside areas but also as a result of their cutting due to the widening of road infrastructure (Lahothi et al. 2020).

Among the methods of limiting air pollution from non-road machinery, we can point to those related to policy, which by regulations allowing limits on exhaust gas emissions restricts the use of technologically older designs, or the search for innovative solutions in the studied group. The authors notice the research on small engines used in many industries, most often in real working conditions, these are e.g. combustion chain saws (Lijewski et al. 2017), energy generators (Lijewski et al. 2017), scooters (Lijewski et al. 2021) wood chippers (Warguła et al. 2020c; 2020d; e), combustion scythes (Zardini et al. 2019).

However, there is also a perceived lack of research on a selected group of drives in identical operating conditions in order to compare them and assess the impact of applying innovative in this group of drives, design solutions. This paper presents tests of small engine emissions in laboratory conditions on an engine chassis dynamometer, the emissions of which were determined to coincide with European Union guidelines (Regulation 2016/1628/EU). Tests were carried out on a popular, commercially available propulsion unit with a carburettor Lifan GX 390 supply system and on the most innovative commercial propulsion unit on the market with an electronically controlled carburettor, Honda iGX 390 . Then, three versions of the Lifan GX 390 engine, modernised by the authors, were tested. The modernisations concerned changing the fuel supply system from a carburettor to an electronic ignition and injection system or changing the fuel used to alternative gaseous fuels LPG and CNG using a design based on a carburettor adapted to gaseous fuels.

\section{Materials And Methods}


Propulsion units commonly used to drive non-road machinery were examined. Five designs were studied, two commercial and three innovative designs developed by the authors. The first propulsion unit tested was the SI Lifan GX390 spark-ignition engine (License: American Honda Motor Company, Inc., Torrance, CA, USA), a design with the most popular and cheapest fuel supply system. It is based on a classic carburettor system. The characteristics of the power unit are presented in Table A.1. The second power unit tested is the SI Honda iGX 390 internal combustion engine (Honda Motor Co., Ltd., Kumamoto Factory, Kumamoto, Japan) with the most innovative fuel supply system in this group of engines. The fuel supply system of this engine is characterised by an electronically controlled carburettor flap. The characteristics of this propulsion unit are also presented in Table A.1. The next tested propulsion units are based on the modernisation of the Lifan GX 390 engine. The modernisations concern the implementation of innovative fuel supply systems developed by the authors who are employees of the Poznań University of Technology, Poznań, Poland. The third engine tested is a Lifan GX 390 with a fuel supply system adapted to LPG, based on a carburettor adapted to gaseous fuels, engine characteristics are presented in Table A.2 (Warguła et al. 2020b; 2020d). The fourth engine tested was a Lifan GX 390 with a fuel supply system adapted for CNG, based on a carburettor adapted for gaseous fuels, the engine characteristics are presented in Table A.2 (Warguła et al. 2020c). The fifth and last engine was the Lifan GX 390 engine (also called the German GX 390 engine, depending on the engine distributor in the European market). It was characterised by the use of an innovative fuel supply system based on an electronically controlled integrated injection and ignition system operating in feedback through the use of a wideband oxygen sensor in the exhaust gases. The engine characteristics are shown in Table A.2 and design details are available in the referenced publications (Warguła et al. 2020a; 2020e; Warguła 2019). Commercial engines and fuel supply system diagrams of all tested systems are shown in Fig. 2.

The test methodology for the assessment of exhaust gas emissions was adopted in accordance with the European Union guidelines (Regulation 2016/1628/EU) for the testing of non-road mobile machinery equipped with low-power internal combustion engines. The Stage $V$ engines tested fall into the NRS-v/vr1 b category (Table A.3) and are affected by the $\mathrm{G} 2$ test cycle (Table A.4), whose weighting factors of the ISO 8178 type B test cycle are shown in Table A.5 and emission limits in Table A.6.

The tests were carried out on an engine chassis dynamometer, adapted to be used with low-power internal combustion engines, the diagram of which is shown in Fig. 3. During the tests, the following values were recorded: rotational speed and torque, on the basis of which power output was determined. Simultaneously, the emission of exhaust gases was recorded: $\mathrm{CO}, \mathrm{HC}, \mathrm{NO}_{\mathrm{x}}, \mathrm{CO}_{2}$. For each tested engine, the test was performed in ten repetitions, and the test results were subjected to statistical analysis. Axion $\mathrm{RS}+$, a typical portable emission measurement system (PEMS) from Global MRV, was used for the exhaust emissions test. Table A.7 shows its technical specification. The emission tests analysed the levels of hydrocarbons $(\mathrm{HC})$, carbon monoxide (CO), carbon dioxide $\left(\mathrm{CO}_{2}\right)$ and nitrogen oxides $\left(\mathrm{NO}_{\mathrm{x}}\right)$. The measuring instrument used in the experiments measured concentrations expressed in vol.\% or ppmv. As a result, more measurable emissions were determined. Emissions were calculated on the basis of 
measured concentrations of the tested compounds and the mass of air delivered to the combustion chamber by measuring the pressure in the intake manifold.

Table A.8 presents the characteristics of the fuels used to power the engines during the tests. Commonly available composition of gaseous fuels (especially natural gas) varies in different geographical areas, the authors used gas available on the Central European market for the tests (Kuczyński et al. 2020).

\section{Results And Discussion}

The recorded test results cover a larger area of operating conditions than required by the European type approval regulations. The results of exemplary characteristics (torque, speed, power, $\mathrm{CO}, \mathrm{CO}_{2}, \mathrm{HC}, \mathrm{NO}_{\mathrm{x}}$ emissions and fuel consumption) during the research test are shown in Fig. 4, grey marking the area of operating conditions used for analysis according to ISO 8178 type B. The analysis was conducted under stable speed and torque conditions.

The average value of pollutant emissions at the operating points determined according to ISO 8178 Type $B$ with consideration of weighting factors (Table A.5) is presented in Table A.9. The average value of the NRSC test emissions T_NRSC was determined according to Eq. (1), where W denotes the contribution of the selected operating conditions to the total test analysis and $\mathrm{E}$ denotes the pollutant emissions under the selected conditions, the assigned numerical subscripts denote the mode number according to Table A.5.

$$
T_{N R S C}=W_{1} \bullet E_{1}+W_{2} \bullet E_{2}+W_{3} \bullet E_{3}+W_{4} \bullet E_{4}+W_{5} \bullet E_{5}+W_{6} \bullet E_{6}
$$

1

Exhaust gas emissions from small SI engine analysed in the European Union during type approval tests concern $\mathrm{CO}$ and $\mathrm{HC}+\mathrm{NO}_{\mathrm{x}}$. All the power units tested do not exceed the permissible emission limits ( $\mathrm{CO}$ in Fig. $5 \mathrm{a}$ and $\mathrm{HC}+\mathrm{NO}_{x}$ in Fig. $5 \mathrm{~b}$ ). The authors performed an analysis of the percentage comparison of emissions during engine dynamometer tests and the permissible emission limits, according to Eq. (2):

$$
E U / T=\frac{X_{E U}-X_{T}}{X_{E U}} \bullet 100 \%
$$

2, where: EU - reference to emission limits described in European Union regulations, $T$ - emission test results of tested designs (commercial engines: A - German GX 390, B - Honda iGX 390; innovative designs: C - LPG-fuelled engine, D - CNG-fuelled engine, E - engine with electronic fuel injection),

$X$ - values from approval regulations or research tests according to the subscript (Fig. 5c).

The commercial design solutions (for the Lifan GX 390 and Honda iGX 390 engine, respectively) are characterised by lower $\mathrm{CO}$ emissions below the permissible standards by $33 \%$ and $8 \%$, while $\mathrm{HC}+\mathrm{NO}_{\mathrm{x}}$ emissions by $43 \%$ and $51 \%$. It may be noted that the most innovative commercial design (Honda iGX 
390) is characterised by higher $\mathrm{CO}$ emissions, being close to the permissible limit, while the design reduces $\mathrm{HC}+\mathrm{NO}_{\mathrm{x}}$ emissions by almost half of the permissible standards. When setting emission limits, legislators consult with scientists and manufacturers on the feasibility of meeting the requirements. The set limits are met by classically used designs with a carburettor supply system and innovative ones with an electronically controlled carburettor throttle flap.

The innovative solutions developed by the authors are aimed at limiting the emission of pollutants through the use of electronic fuel injection (gasoline) or fuel switching while maintaining a carburettor adapted to gaseous fuels. The results of the research show that the use of LPG and CNG fuels may reduce $\mathrm{CO}$ emission by $94 \%$ and $97 \%$, respectively, with respect to the limits allowed in the European Union. On the other hand, the reduction of $\mathrm{HC}+\mathrm{NOx}$ is at the level of $10 \%$ and $60 \%$. It may be noticed that the engine fuelled by LPG significantly reduces $\mathrm{CO}$ while having the highest $\mathrm{HC}+\mathrm{NO}_{x}$ emission among the tested engines. The second tested construction adapted to gaseous fuels, i.e. the engine fuelled by CNG is characterised by the lowest emission of pollutants taken into account during the EU type approval tests; this emission is the lowest among the tested engines. The use of an electronic fuel supply system with gasoline reduced $\mathrm{CO}$ emissions by $67 \%$ and $\mathrm{HC}+\mathrm{NO}_{x}$ by $50 \%$. This result is better than the commercial units, but is inferior to the CNG-fuelled engine.

The research was extended to the analysis of exhaust emissions beyond the components included in the approval tests used in the European Union. $\mathrm{CO}_{2}$ emissions were measured, as well as $\mathrm{HC}$ and $\mathrm{NOx}$ emissions independently. Controlling $\mathrm{CO}_{2}$ emissions is also important as this gas contributes to the greenhouse effect, but is better recycled by the environment than the others. All the components tested $\left(\mathrm{CO}, \mathrm{CO}_{2}, \mathrm{HC}, \mathrm{NO}_{\mathrm{x}}\right)$ are plotted against each other in the figures $\left(\mathrm{CO}\right.$ and $\mathrm{CO}_{2}$ in Fig. 6 and $\mathrm{HC}$ and $\mathrm{NO}_{\mathrm{x}}$ in Fig. 7). The results of these tests will make it possible to assess the impact of the retrofits carried out. For this purpose, the results of tests on commercial units (A - German GX 390 and B - Honda iGX 390) have been summed up and the arithmetic mean has been drawn, making it possible to relate the results of retrofitting (of the innovative designs tested: C - LPG-fuelled engine, D - CNG-fuelled engine, E - electronic fuel injection engine) in relation to commercial solutions, denoted further by the $\mathrm{K}$ index. Comparison of $\mathrm{CO}, \mathrm{CO}_{2}, \mathrm{HC}, \mathrm{NO}_{\mathrm{x}}$ emissions of innovative designs ( $\mathrm{C}$ - LPG-fuelled engine, D - CNG-fuelled engine, $\mathrm{E}$ electronic fuel injection engine) with commercial $\mathrm{K}$ designs reveals that the CNG-fuelled engine has the best results. Its emissions are sequentially lower than commercial designs by $96 \%, 72 \%, 50 \%$ and has the lowest increase in $\mathrm{NO}_{x}$ emissions by $9 \%$.A common effect of fuel switching from gasoline to $\mathrm{CNG}$, consistent with the findings of other authors, is the reduction, of CO (Usman and Hayat 2019; Yaser et al. 2013; Geok et al. 2009; Shamekhi et al. 2006), $\mathrm{CO}_{2}$ (Usman and Hayat 2019; Jahirul et al. 2010; Geok et al. 2009; Shamekhi et al. 2006) and HC (Quintili and Castellani 2020; Usman and Hayat 2019; Bielaczyc et al. 2016; Yaser et al. 2013; Merkisha et al. 2012a; Zhang et al. 2011; Jahirul et al. 2010; Shamekhi et al. 2006) and an increase in $\mathrm{NO}_{x}$ (Singh et al. 2016; Huang et al. 2016; Mohamed 2006). CNG is composed of lighter hydrocarbons and the hydrogen to carbon ratio in CNG is much higher than in gasoline. This affects the combustion process in the cylinder, reducing the proportion of incomplete combustion and thus lower $\mathrm{CO}$ and $\mathrm{HC}$ emissions, while it favours an increase in $\mathrm{NO}_{\mathrm{x}}$ emissions which may be due to an 
increase in combustion temperature. On the other hand, the reduction in $\mathrm{CO}_{2}$ is mainly associated with a reduction in fuel consumption. The reduction of $\mathrm{NO}_{\mathrm{x}}$ emissions after fuel switching is characteristic of diesel engines (Merkisz et al. 2015). The use of LPG fuel contributed to a $93 \%$ reduction in CO and $53 \%$ reduction in $\mathrm{HC}$ emissions, while a $485 \%$ increase in $\mathrm{CO}_{2}$ and $234 \%$ increase in NOx emissions is noticeable. A common effect of fuel switching from petrol to LPG, consistent with the findings of other authors, is a reduction of CO (Çinar et al. 2016; Myung et al. 2014; Gümüş 2009), HC (Duc and Duy 2018; Çinar et al. 2016; Myung et al. 2014; Gümüş 2009) and an increase in $\mathrm{CO}_{2}$ (Myung et al. 2014), $\mathrm{NO}_{\mathrm{x}}$ (Çinar et al. 2016; Duc and Duy 2018). The combustion of LPG fuel is characterised by a more homogeneous fuel input mixture. Thus, there is better combustion and lower $\mathrm{HC}$ and $\mathrm{CO}$ emissions are produced, which favours $\mathrm{NO}_{x}$ emissions. On the other hand, this fuel has a lower carbon content and is characterised by higher fuel consumption, which has a strong effect on $\mathrm{CO}_{2}$ emissions. Merkisz and Radzimirski, 2006 show that emissions are significantly affected by the level of technical sophistication of the LPG and gasoline fuel supply system, while Dziewiatkowski et al. 2020 (Dziewiatkowski et al. 2020) indicate that emissions are also affected by the wear of fuel supply system components. The use of an electronically controlled gasoline injection system reduced $\mathrm{CO}$ emissions by $59 \%, \mathrm{CO}_{2}$ emissions by $71 \%, \mathrm{HC}$ emissions by $18 \%$, and increased $\mathrm{NO}_{\mathrm{x}}$ emissions by $10 \%$ relative to commercial solutions based on carbureted fuel systems. The reduction of $\mathrm{CO}$ (Yao et al. 2017) and $\mathrm{HC}$ (Yao et al. 2017) and a slight increase in $\mathrm{NO}_{\mathrm{x}}$ emissions (Yao et al. 2017) by using electronic fuel injection relative to a carbureted system are consistent with the findings of other researchers. Electronic fuel injection with mixture control promotes better matching of the fuel-air mixture composition to the operating conditions, and ensures operation close to stoichiometric mixtures, unlike carbureted systems that operate on enriched mixtures (Warguła et al. 2020d). Lower $\mathrm{HC}$ and $\mathrm{CO}$ emissions, this promotes higher $\mathrm{NO}_{\mathrm{x}}$ emissions, and reduced fuel consumption through better fuel-air mixture selection reduces fuel consumption and thus $\mathrm{CO}_{2}$ emissions.

The research has shown that an advantageous direction of development in the studied group of engines is the use of electronically controlled fuel injection or remaining with a carburettor fuel supply system and extending it with the possibility of fueling with gaseous fuels, of which CNG was characterised by the best effects in terms of reducing pollutant emissions. The authors recognise that access to and popularity of gaseous fuels will increase as biogas plants (Wąs et al. 2020) (increase in types of biodegradable materials (Czarnecka-Komorowska and Wiszumirska, 2020; Knitter et al. 2019; CzarneckaKomorowska et al. 2018) and backyard natural gas fueling stations (Kuczyński et al. 2019) become more common. In parallel, gas-fuelled designs can be developed with electronically controlled gaseous fuel injection systems. In addition, all designs can be investigated for the impact of the use of exhaust aftertreatment systems (Merkisz and Siedlecki 2017), adaptive control systems (Irmesus et al. 2014) and fuel additives (Le Anh et al. 2014).

\section{Conclusion}

The results of the research presented in the paper show that small SI engines intended for non-road machines used e.g. in machines for the construction and maintenance of road infrastructure, irrespective 
of the level of innovation of the fuel supply system, do not exceed the permissible pollutant emission limits provided for in the NRSC type-approval tests applied in the European Union. The limits of permissible emissions are relatively high in relation to other groups of engines, thus, the innovative constructional solutions limiting the emissions $\left(\mathrm{CO}, \mathrm{CO}_{2}, \mathrm{HC}\right.$ and $\left.\mathrm{NO}_{\mathrm{x}}\right)$, developed and examined by the authors, may contribute to legislative actions towards their tightening. A gasoline-fuelled design with an innovative injection system reduces $\mathrm{CO}, \mathrm{CO}_{2}, \mathrm{HC}$ emissions, as does an engine with a carburettor supply system adapted to CNG gas fuel. The CNG-fuelled engine had the highest pollutant emissions, except for $\mathrm{NO}_{x}$, which was the lowest for commercial engines (with a carburettor fuel supply system with mechanical or electrical throttle flap control) fuelled with gasoline. The LPG-fuelled engine with a carburettor system was characterised by a reduction in $\mathrm{CO}$ and $\mathrm{HC}$ and an increase in $\mathrm{CO}_{2}$ and $\mathrm{NO}_{\mathrm{x}}$ emissions.

Small SI engine fuel supply systems for non-road machines should adapt to their design solutions found in other engine groups that meet more stringent emission requirements. However, if legislators do not restrict the use of technologically obsolete designs, innovative solutions will not be used as they are more expensive. Small engine emissions are relatively high and therefore constitute an important problem for the environment and human health, mainly for machine operators working, inter alia, in the sector of the maintenance and construction of transport infrastructure.

\section{Declarations}

\section{Ethical Approval}

Not applicable

\section{Consent to Participate}

Not applicable

\section{Consent to Publish}

Not applicable

\section{Authors Contributions}

Validation, Ł.W.; resources, Ł.W., P.L. and M.K.; methodology, Ł.W., P.L.; writing-original draft preparation, Ł.W., M.K. and P.L.; conceptualization, Ł.W.; data curation, Ł.W.; software, Ł.W.; investigation, Ł.W. and P.L.; formal analysis, Ł.W.; visualization, Ł.W.; writing-review and editing, M.K., Ł.W.; supervision, Ł.W.; project administration, Ł.W.; funding acquisition, Ł.W. All authors have read and agreed to the published version of the manuscript.

\section{Funding}


Research was performed as part of the project "Interdisciplinary Dean's Grant (IDG) of Poznan University of Technology" determined in the subject for the 2020 year-air quality in Poznan and how to improve it. Project title: "Design and research of mobile machines chipping wastes from urban agriculture processes for innovative construction solutions limiting the impact on the natural environment and machine operators" (33/32/SIGR/3334) financed by the Poznan University of Technology.

\section{Competing Interests}

Not applicable

\section{Availability of data and materials}

Not applicable

\section{References}

1. Amorim JH, Valente J, Cascão P, Rodrigues V, Pimentel C, Miranda Al, Borrego C (2013) Pedestrian exposure to air pollution in cities: modeling the effect of roadside trees. Advances in Meteorology 2013:1-7

2. Andwari AM, Said MFM, Aziz AA, Esfahanian V, Salavati-Zadeh A, Idris MA, Perang MRM, Jamil HM (2018) Design. Modeling and Simulation of a High-Pressure Gasoline Direct Injection (GDI) Pump for Small Engine Applications. J. Mech. Eng. 6(1):107-120

3. Arapatsakos $\mathrm{Cl}$, Karkanis AN, Sparis PD (2003) Behavior of a small four-stroke engine using as fuel methanol-gasoline mixtures. SAE Technical Paper No. 2003-32-0024

4. Bielaczyc P, Szczotka A, Woodburn J (2016) A comparison of exhaust emissions from vehicles fuelled with petrol, LPG and CNG, In IOP Conference Series: Materials Science and Engineering, Scientific Conference on Automotive Vehicles and Combustion Engines (KONMOT 2016), Krakow, Poland, September 22-23, 2016, Vol. 148, p. 012060

5. Celik MB, Özdalyan B, Alkan F (2011) The use of pure methanol as fuel at high compression ratio in a single cylinder gasoline engine. Fue/ 90(4):1591-1598

6. Cepeda M, Schoufour J, Freak-Poli R, Koolhaas CM, Dhana K, Bramer WM, Franco OH (2017) Levels of ambient air pollution according to mode of transport: a systematic review. The Lancet Public Health. 2(1):e23-e34

7. Çinar C, Şahin F, Can Ö, Uyumaz A (2016) A comparison of performance and exhaust emissions with different valve lift profiles between gasoline and LPG fuels in a SI engine. Applied Thermal Engineering 107:1261-1268.

8. Colvile RN, Hutchinson RJ, Mindell JS, Warren RF (2001) The transport sector as a source of air pollution. Atmospheric environment 35(9):1537-1565

9. Czarnecka-Komorowska D, Wiszumirska K (2020) Sustainability design of plastic packaging for the Circular Economy. Polimery 65:8-17 
10. Czarnecka-Komorowska D, Wiszumirska K, Garbacz T (2018) Films LDPE/LLDPE made from postconsumer plastics: Processing, structure, mechanical properties. Adv. Sci. Technol. Res. J. 12:134142

11. Darzi M, Johnson D, Ulishney C, Clark N (2018) Low pressure direct injection strategies effect on a small SI natural gas two-stroke engine's energy distribution and emissions. Applied energy 230:15851602

12. Directive 97/68/EC of the European Parliament and of the Council of 16 December 1997 on the approximation of the laws of the Member States relating to measures against the emission of gaseous and particulate pollutants from internal combustion engines to be installed in non-road mobile machinery

13. Dorosz P (2018) Compressed and liquefied natural gas as an alternative for petroleum derived fuels used in transport (original text in Polish: Sprężony i skroplony gaz ziemny jako alternatywa dla paliw ropopochodnych wykorzystywanych w transporcie), Polit. Energetyczna-Energy Policy J. 21:85-98

14. Duc KN, Duy VN (2018) Study on performance enhancement and emission reduction of used fuelinjected motorcycles using bi-fuel gasoline-LPG. Energy for Sustainable Development 43:60-67

15. Dziewiatkowski M, Szpica D, Borawski A (2020) Evaluation of impact of combustion engine controller adaptation process on level of exhaust gas emissions in gasoline and compressed natural gas supply process. Eng. Rural Dev 541-548

16. Ehrenberger S, Seum S, Pregger T, Simon S, Knitschky G, Kugler U (2021)Land transport development in three integrated scenarios for Germany-Technology options. energy demand and emissions. Transportation Research Part D: Transport and Environment 90:102669

17. EU Directive 2014/94/EU of the European Parliament and of the Council of 22 October 2014 on the Deploy-Ment of Alternative Fuels Infrastructure Text with EEA Relevance; EU: Strasbourg. France. 2014.

18. Elsadek M, Liu B, Lian Z, Xie J (2019) The influence of urban roadside trees and their physical environment on stress relief measures: A field experiment in Shanghai. Urban Forestry \& Urban Greening 42:51-60.

19. Fontana G, Galloni E (2009) Variable valve timing for fuel economy improvement in a small sparkignition engine. Applied Energy 86(1):96-105.

20. Gałuszka A, Migaszewski ZM, Podlaski R, Dołęgowska S, Michalik A (2011) The influence of chloride deicers on mineral nutrition and the health status of roadside trees in the city of Kielce. Poland. Environmental Monitoring and Assessment 176(1):451-464

21. Geok HH, Mohamad TI, Abdullah S, Ali Y, Shamsudeen A (2009) Experimental investigation of performance and emissions of a sequential port injection compressed natural gas converted engine. SAE Technical Paper No. 2009-32-0026

22. Gnap J, Varjan P, Durana P, Kostrzewski M (2019) Research on relationship between freight transport and transport infrastructure in selected European countries. Transport Problems 14(3):63-74 
23. Gümüş M (2009) The Effect Of LPG Usage Rate On Performance And Emission Characteristics In A Double Fuel Injection Spark Ignition Engine (original text in Turkish: Çift Yakit Enjeksiyonlu Buji Ateşlemeli Bir Motorda LPG Kullanim Oraninin Performans Ve Emisyon Karakteristiklerine Etkisi) Gazi Üniversitesi Mühendislik Mimarlık Fakültesi Dergisi 24(2)

24. Homdoung N, Tippayawong N, Dussadee N (2015) Performance and emissions of a modified small engine operated on producer gas. Energy conversion and management 94:286-292

25. Huang X, Wang Y, Xing Z, Du K (2016) Emission factors of air pollutants from CNG-gasoline bi-fuel vehicles: Part II. CO, HC and NOx, Science of the Total Environment 565:698-705 doi:10.1016/j.scitotenv.2016.05.069.

26. Irimescu A, Vasiu G, Tordai GT (2014) Performance and emissions of a small scale generator powered by a spark ignition engine with adaptive fuel injection control. Applied energy 121:196-206

27. Iyer RC (2020) Experimental investigations on the influence of compression ratio and piston crown geometry on the performance of biogas fuelled small spark ignition engine. Renewable Energy 146:997-1009

28. Jahirul MI, Masjuki HH, Saidur R, Kalam MA, Jayed HM, Wazed MA (2010) Comparative engine performance and emission analysis of CNG and gasoline in a retrofitted car engine. Appl. Therm. Eng. 30:2219-2226

29. Ju J-H, Park J-Y, Yoon Y-H (2020) Influence of Different Types of Land Use on the Contents of Potentially Toxic Elements and De-icing Salts in Roadside Soils and Trees in Urban Areas. Sustainability 12:8985. https://doi.org/10.3390/su12218985

30. Kamińska M, Rymaniak Ł, Daszkiewicz P, Lijewski P (2019) Test guidelines for evaluation real driving emission two-way vehicles. In MATEC Web of Conferences, 2nd International Scientific and Practical Conference "Energy-Optimal Technologies, Logistic and Safety on Transport" (EOT-2019), Lviv, Ukraine, September 19-20, 2019, Vol. 294, p. 02009

31. Kim JY, Park J, Choi J, Kim J (2020) Determination of Metal Concentration in Road-Side Trees from an Industrial Area Using Laser Ablation Inductively Coupled Plasma Mass Spectrometry. Minerals 10:175 https://doi.org/10.3390/min10020175

32. Kuczyński S, Liszka K, Łaciak M, Olijnyk A, Szurlej A (2019) Experimental Investigations and Operational Performance Analysis on Compressed Natural Gas Home Refueling System (CNG-HRS). Energies 12:4511

33. Knitter M, Czarnecka-Komorowska D, Czaja-Jagielska N, Szymanowska-Powalowska D (2019) Manufacturing and Properties of Biodegradable Composites Based on Thermoplastic Starch/Polyethylene-Vinyl Alcohol and Silver Particles. In Advances in Manufacturing II. Volume 4Mechanical Engineering; Gapinski, B., Szostak, M., Ivanov, V., Eds.; Springer: Berlin, Germany, 2019; pp. 610-624

34. Lahoti S, Lahoti A, Joshi RK, Saito O (2020) Vegetation Structure, Species Composition, and Carbon Sink Potential of Urban Green Spaces in Nagpur City, India, Land (9):107 https://doi.org/10.3390/land9040107 
35. Le Anh T, Duc KN, Thu HTT, Van TC (2013) Improving performance and reducing pollution emissions of a carburetor gasoline engine by adding $\mathrm{HHO}$ gas into the intake manifold. SAE Technical Paper No. 2013-01-0104

36. Li L, Liu Z, Wang H, Deng B, Wang Z, Xiao Z, Su Y, Jiang B (2003) Development of a Gas-phase LPG Injection System for a Small SI Engine. SAE Technical Paper No. 2003-01-3260

37. Lijewski P, Fuć P, Dobrzyński M, Markiewicz F (2017) Exhaust emissions from small engines in handheld devices. In MATEC Web of Conferences, VII International Congress on Combustion Engines, Poznań, Poland, June 27-29, 2017, Vol. 118, p. 00016

38. Lijewski P, Fuć P, Markiewicz F, Dobrzański M (2019) Problems of exhaust emissions testing from machines and mobile devices in real operating conditions. Combust. Engines 179:292-296

39. Lijewski P, Kozak M, Fuć P, Rymaniak Ł, Ziółkowski A (2020) Exhaust emissions generated under actual operating conditions from a hybrid vehicle and an electric one fitted with a range extender, Transportation Research Part D: Transport and Environment 78:102183

40. Lijewski P, Szymlet N, Fuć P, Domowicz A, Rymaniak $Ł$ (2021) The effect of start-stop systems on scooter exhaust emissions, Transportation Research Part D: Transport and Environment 91:102684

41. Lin WY, Chang YY, Hsieh YR (2010) Effect of ethanol-gasoline blends on small engine generator energy efficiency and exhaust emission. Journal of the Air \& Waste Management Association 60(2):142-148

42. Lin B, Meyers J, Barnett $\mathrm{G}$ (2015) Understanding the potential loss and inequities of green space distribution with urban densification. Urban forestry \& urban greening 14(4):952-958

43. Liu Y, Chao F (2020) Decouple transport CO2 emissions from China's economic expansion: A temporal-spatial analysis. Transportation Research Part D: Transport and Environment 79:102225

44. Ma J, Rao J, Kwan MP, Chai Y (2020) Examining the effects of mobility-based air and noise pollution on activity satisfaction. Transportation Research Part D: Transport and Environment 89:102633

45. Mohamed ES (2016) Experimental study on the effect of active engine thermal management on a bifuel engine performance, combustion and exhaust emissions. Applied Therma/ Engineering 106:1352-1365. doi:10.1016/j.applthermaleng.2016.06.123.

46. Meekan MG, Duarte CM, Fernández-Gracia J, Thums M, Sequeira AMM, Harcourt R, Eguíluz VM (2017) The ecology of human mobility. Trends in ecology \& evolution 32(3):198-210

47. Merkisz J, Dobrzyński M, Kozak M, Lijewski P, Fuć $P$ (2016) Environmental aspects of the use of cng in publicurban transport. Altern. Fuels Technol. Environ. Cond. 1-22

48. Merkisz J, Fuć P, Bajerlein M, Dobrzynski M, Rymaniak Ł, Ziółkowski A (2012a) Reducing the Negative Impact of Public Transport on the Environment by Using CNG as a Fuel. J. KONBiN22:147158

49. Merkisz J, Pielecha J, Fuć P, Lijewski P (2021b) The analysis of the PEMS measurements of the exhaust emissions from city buses using different research procedures. In 2012 IEEE Vehicle Power and Propulsion Conference, Seul, Korea, October 9, 2012b, 903-907. 
50. Merkisz J, Pielecha J, Gis W, Gis M, Jasiński R (2015) Comparative assessment of exhaust emission buses: Powered CNG and Diesel. Combust. Engines 162:775-781.

51. Merkisz J, Radzimirski S (2006) Is propane-butane gas an ecological fuel? (original text in Polish: Czy gaz propan-butan jest paliwem ekologicznym?), Combust. Engines 45:45-57

52. Merkisz J, Siedlecki M (2017) Specific emissions analysis for a combustion engine in dynamometer operation in relation to the thermal state of the exhaust gas after treatment systems in a modified NRSC test. In MATEC Web of Conferences, VII International Congress on Combustion Engines, Poznań, Poland, June 27-29, 2017, Vol. 118, p. 00027

53. Mikulski M, Wierzbicki S, Śmieja M, Matijošius J (2015) Effect of CNG in a fuel dose on the combustion process of a compression-ignition engine. Transport 30(2):162-171

54. bin Mohd Zain MS, bin Mohamed Soid SN, bin Mior Abd Majid MF, bin Zahelem MN (2019) Performance characteristics of a small engine fueled by liquefied petroleum gas. In Advanced Engineering for Processes and Technologies; Ismail. A., Abu Bakar M., Öchsner. A. Eds.; Advanced Structured Materials; Springer: Berlin. Germany; Cham. Germany. 2019, Vol. 102. pp. 207-214.

55. Myung CL, Ko A, Lim Y, Kim S, Lee J, Choi K, Park S (2014) Mobile source air toxic emissions from direct injection spark ignition gasoline and LPG passenger car under various in-use vehicle driving modes in Korea. Fuel Processing Technology 119:19-31

56. Nieuwenhuijsen MJ (2018) Influence of urban and transport planning and the city environment on cardiovascular disease. Nat Rev Cardio/ 15:432-438 https://doi.org/10.1038/s41569-018-0003-2

57. Niinikoski J, Ewalds J, Heikkinen E, Kotilainen J, Kääriäinen M, Tammi K, Kiviluoma P, Korhonen A, Kuosmanen P (2016) Methods for Reducing Emissions of Small Internal Combustion Engines, In Proceedings of the 11th International DAAAM Baltic Conference. Industrial Engineering. Tallinn. Estonia. 20-22 April 2016

58. Ozdemir H (2019) Mitigation impact of roadside trees on fine particle pollution. Science of the Total Environment 659:1176-1185

59. Quintili A, Castellani B (2020) The Energy and Carbon Footprint of an Urban Waste Collection Fleet: A Case Study in Central Italy. Recycling 5:25

60. Ravi K, Porpatham E, Alexander J (2021) Effects of Methanol Substitution on Performance and Emission in a LPG-Fueled SI Engine. In: Gupta A., Mongia H., Chandna P., Sachdeva G. (eds) Advances in IC Engines and Combustion Technology. NCICEC 2019. Lecture Notes in Mechanical Engineering. Springer, Singapore, (2021) https://doi.org/10.1007/978-981-15-5996-9_16

61. In National Conference on IC Engines and Combustion, NCI (pp. 193-205). Springer. Singapore.

62. Regulation (EU). On Requirements for Emission Limit Values of Gaseous and Particulate Pollutants and Type-approval with Respect to Internal Combustion Engines for Mobile Machines Non-road. Amending Regulations (EU) No 1024/2012 and (EU) No 167/2013 and Amending and Repealing Directive 97/68/WE. No 2016/1628 of the European Parliament and of the Council of 14 September 2016. Off. J. Eur. Union. 2016. 252. 53-117. 
63. Regulation (EC) No 715/2007 of the European Parliament and of the Council of 20 June 2007 on type approval of motor vehicles with respect to emissions from light passenger and commercial vehicles (Euro 5 and Euro 6) and on access to vehicle repair and maintenance information (Text with EEA relevance)

64. Regulation (EC) No 595/2009 of the European Parliament and of the Council of 18 June 2009 on type-approval of motor vehicles and engines with respect to emissions from heavy duty vehicles (Euro $\mathrm{VI}$ ) and on access to vehicle repair and maintenance information and amending Regulation (EC) No 715/2007 and Directive 2007/46/EC and repealing Directives 80/1269/EEC, 2005/55/EC and 2005/78/EC (Text with EEA relevance)

65. Regulation (EU) 2019/1242 of the European Parliament and of the Council of 20 June 2019 setting CO2 emission performance standards for new heavy-duty vehicles and amending Regulations (EC) No 595/2009 and (EU) 2018/956 of the European Parliament and of the Council and Council Directive 96/53/EC

66. Redweik P, Catita C, Henriques F, Rodrigues A (2019) Solar Glare Vulnerability Analysis of Urban Road Networks-A Methodology. Energies 12:4779 https://doi.org/10.3390/en12244779

67. Ren C, Chen L, Wang Z, Zhang B, Xi Y, Lu C (2019) Spatio-Temporal Changes of Forests in Northeast China: Insights from Landsat Images and Geospatial Analysis. Forests 10:937 https://doi.org/10.3390/f10110937

68. Ribeiro CB, Martins KG, Gueri MVD, Pavanello GP, Schirmer WN (2018) Effect of anhydrous ethanol/gasoline blends on performance and exhaust emissions of spark-ignited non-road engines. Environ. Sci. Pollut.Res. 25:24192-24200

69. Rosłon-Szeryńska E, Gajowniczek A, Gawłowska A (2019) Road traffic safety and roadside trees on the example of the Minsk poviat, (orginal text in Polish: Bezpieczeństwo ruchu drogowego a drzewa przydrożne na przykładzie powiatu mińskiego), Drogownictwo 3

70. Rymaniak $Ł$ (2018) Comparison of the combustion engine operating parameters and the ecological indicators of an urban bus in dynamic type approval tests and in actual operating conditions. In MATEC Web of Conferences, The 1st International Conference on Industrial, Electrical and Electronics (ICIEE 2018), Anyer, Indonesia, September 4-5, 2018, Vol. 118, p. 00009

71. Rymaniak Ł, Lijewski P, Kamińska M, Fuć P, Kurc B, Siedlecki M, Kalociński T, Jagielski A (2020) The role of real power output from farm tractor engines in determining their environmental performance in actual operating conditions. Computers and Electronics in Agriculture 173:105405

72. Sabariah MS, Nabilah AS, Rosli AB, Junaidi ZZ, Mustafar MT (2018) Analysis and simulation of combustion and emission on small engine. In IOP Conference Series: Materials Science and Engineering, 1st International Postgraduate Conference on Mechanical Engineering (IPCME2018), UMP Pekan, Pahang, Malaysia, October 31, 2018, Vol. 469. No. 1. p. 012076

73. Saidi S, Hammami S (2017) Modeling the causal linkages between transport, economic growth and environmental degradation for 75 countries. Transportation Research Part D: Transport and Environment 53:415-427 
74. Schirmer WN, Olanyk LZ, Guedes CLB, Quessada TP, Ribeiro CB, Capanema MA (2017) Effects of air/fuel ratio on gas emissions in a small spark-ignited non-road engine operating with different gasoline/ethanol blends. Environmental Science and Pollution Research 24(25): 20354-20359

75. Shamekhi A, Khatibzadeh N, Shamekhi AH (2006) Performance and emissions characteristics investigation of abi-fuel SI engine fuelled by CNG and gasoline, In: ASME Internal Combustion Engine Division, Spring Technical Conference, Aachen, Germany, May 7-10, 2006, ICES2006-1387, 393-400. doi:10.1016/j.ultsonch.2006.09.003

76. Singh AP, Pal A, Agarwal AK (2016) Comparative particulate characteristics of hydrogen, CNG, HCNG, gasoline and diesel fueled engines. Fuel 185:491-99 doi:10.1016/j.fuel.2016.08.018

77. Subramanian M (2011) Effect of hydrogen in CNG on small engine performance and emissions. SAE Technical Paper No. 2011-24-0202

78. Sulaiman MY, Ayob MR, Meran I (2013) Performance of single cylinder spark ignition engine fueled by LPG. Procedia Eng. 53:579-585

79. Surata IW, Nindhia TGT, Atmika IKA, Negara DNKP, Putra IWEP (2014) Simple conversion method from gasoline to biogas fueled small engine to powered electric generator. Energy Procedia. 52:626632

80. Tartakovsky L, Amiel R, Baibikov V, Fleischman R, Gutman M, Poran A, Veinblat M (2015) SI engine with direct injection of methanol reforming products-first experimental results. SAE Technical Paper No. 2015-32-0712.

81. Usman M, Hayat N (2019) Use of CNG and Hi-octane gasoline in SI engine: A comparative study of performance, emission, and lubrication oil deterioration. Energy Sources Part A Recover. Util. Environ. Eff. $1-15$.

82. Yao Z, Wang Q, He K, Huo H, Ma Y, Zhang Q (2017) Characteristics of real-world vehicular emissions in Chinese cities. Journal of the Air \& Waste Management Association 57(11):1379-1386.

83. Yasar A, Haider R, Tabinda AB, Kausar F, Khan M (2013) A comparison of engine emissions from heavy, medium, and light vehicles for CNG, diesel, and gasoline fuels. Pol. J. Environ. Stud 22(4):1277-1281

84. Yu N, De Jong M, Storm S, Mi J (2013) Spatial spillover effects of transport infrastructure: evidence from Chinese regions. Journal of Transport Geography 28:56-66

85. Wahono B, Setiawan A, Lim O, Praptijanto A, Putrasari Y (2019) Study on the Effect of the Intake Port Configuration on the In-cylinder of Small Engine. In 2019 International Conference on Sustainable Energy Engineering and Application (ICSEEA), Serpong, Indonesia, October 23-24, 2019, 33-36. IEEE

86. Waluś KJ, Warguła $\measuredangle$, Krawiec P, Adamiec JM (2018) Legal regulations of restrictions of air pollution made by non-road mobile machinery - The case study for Europe: A review, Environ. Sci. Pollut. Res. 25:3243-3259

87. Warguła $\downarrow$ (2019) Innovative injection-ignition system in a non-road small engine-construction system. In Proceedings of the Transport Means 2019: 23rd International Scientific Conference, Palanga, Lithuania, October, 2-4, 2019; Part 2. Kaunas University of Technology, pp. 931-935 
88. Warguła Ł, Krawiec P, Waluś KJ, Kukla M (2020a) Fuel Consumption Test Results for a Self-Adaptive, Maintenance-Free Wood Chipper Drive Control System. Applied Sciences 10(8):2727 https://doi.org/10.3390/app10082727

89. Warguła $Ł$, Kukla M, Krawiec P, Wieczorek B (2020b) Reduction in Operating Costs and Environmental Impact Consisting in the Modernization of the Low-Power Cylindrical Wood Chipper Power Unit by Using Alternative Fuel. Energies 13(11): 2995 https://doi.org/10.3390/en13112995

90. Warguła Ł, Kukla M, Lijewski P, Dobrzyński M, Markiewicz F (2020c) Impact of Compressed Natural Gas (CNG) Fuel Systems in Small Engine Wood Chippers on Exhaust Emissions and Fuel Consumption. Energies 13:6709 https://doi.org/10.3390/en13246709

91. Warguła $Ł$, Kukla M, Lijewski P, Dobrzyński M, Markiewicz F (2020d) Influence of the Use of Liquefied Petroleum Gas (LPG) Systems in Woodchippers Powered by Small Engines on Exhaust Emissions and Operating Costs. Energies 13:5773. https://doi.org/10.3390/en13215773

92. Warguła $Ł$, Kukla M, Lijewski P, Dobrzyński M, Markiewicz F (2020e) Influence of Innovative Woodchipper Speed Control Systems on Exhaust Gas Emissions and Fuel Consumption in Urban Areas. Energies 13:3330. https://doi.org/10.3390/en13133330

93. Warguła $Ł$, Waluś KJ, Krawiec $P$ (2018) Small engines spark ignited (SI) for non-road mobile machinery - review. In Proceedings of the Transport Means 2018: 22nd International Scientific Conference, Trakai, Lithuania. October 3-5, 2018a, Part 2. pp. 585-591

94. Warguła $Ł$, Waluś KJ, Krawiec P, Polasik J (2018b) Electronic control injection-ignition systems in propulsion of non-road mobile machinery. J. Mech. Trans. Eng. 70:61-78

95. Warowny W, Tkacz A (2001) Natural gas and its characteristics as fuel for wheeled vehicles (original text in Polish: Gaz ziemny i jego charakterystyka jako paliwa do pojazdów kołowych), Gaz Woda $i$ Technika Sanitarna 75:267-272

96. Wąs A, Sulewski P, Krupin V, Popadynets N, Malak-Rawlikowska A, Szymańska M, Skorokhod I, Wysokiński M (2020) The Potential of Agricultural Biogas Production in Ukraine-Impact on GHG Emissions and Energy Production. Energies 13:5755

97. Weber F, Kowarik I, Säumel I (2014) A walk on the wild side: Perceptions of roadside vegetation beyond trees. Urban Forestry \& Urban Greening 13(2):205-212

98. Wołoszyn R (2003) Natural gas as a vehicle fuel (original text in Polish: Gaz ziemny jako paliwo do napędupojazdów). Eksploatacja i Niezawodność 3:19-22

99. Zaki SA, Toh HJ, Yakub F, Mohd Saudi AS, Ardila-Rey JA, Muhammad-Sukki F (2020) Effects of Roadside Trees and Road Orientation on Thermal Environment in a Tropical City. Sustainability 12:1053 https://doi.org/10.3390/su12031053

100. Zardini AA, Suarez-Bertoa R, Forni F, Montigny F, Otura-Garcia M, Carriero M, Astorga C (2019) Reducing the exhaust emissions of unregulated pollutants from small gasoline engines with alkylate fuel and low-ash lube oil. Environmental research 170:203-214

101. Zhang CH, Xie YL, Wang FS, Ma ZY, Qi DH, Qiu ZW (2011) Emission comparison of light-duty in-use flexible-fuel vehicles fuelled with gasoline and compressed natural gas based on the ECE 15 driving 
cycle. Proc. Inst. Mech. Eng. Part D J. Automob. Eng. 225:90-98

102. Ziółkowski A, Daszkiewicz P, Rymaniak $Ł$, Fuć P, Ukleja P (2019) Analysis of the exhaust emissions from hybrid vehicle during RDE test, In MATEC Web of Conferences, 2nd International Scientific and Practical Conference "Energy-Optimal Technologies, Logistic and Safety on Transport" (EOT-2019), Lviv, Ukraine, September 19-20, 2019, Vol. 294, p. 02002.

\section{Figures}

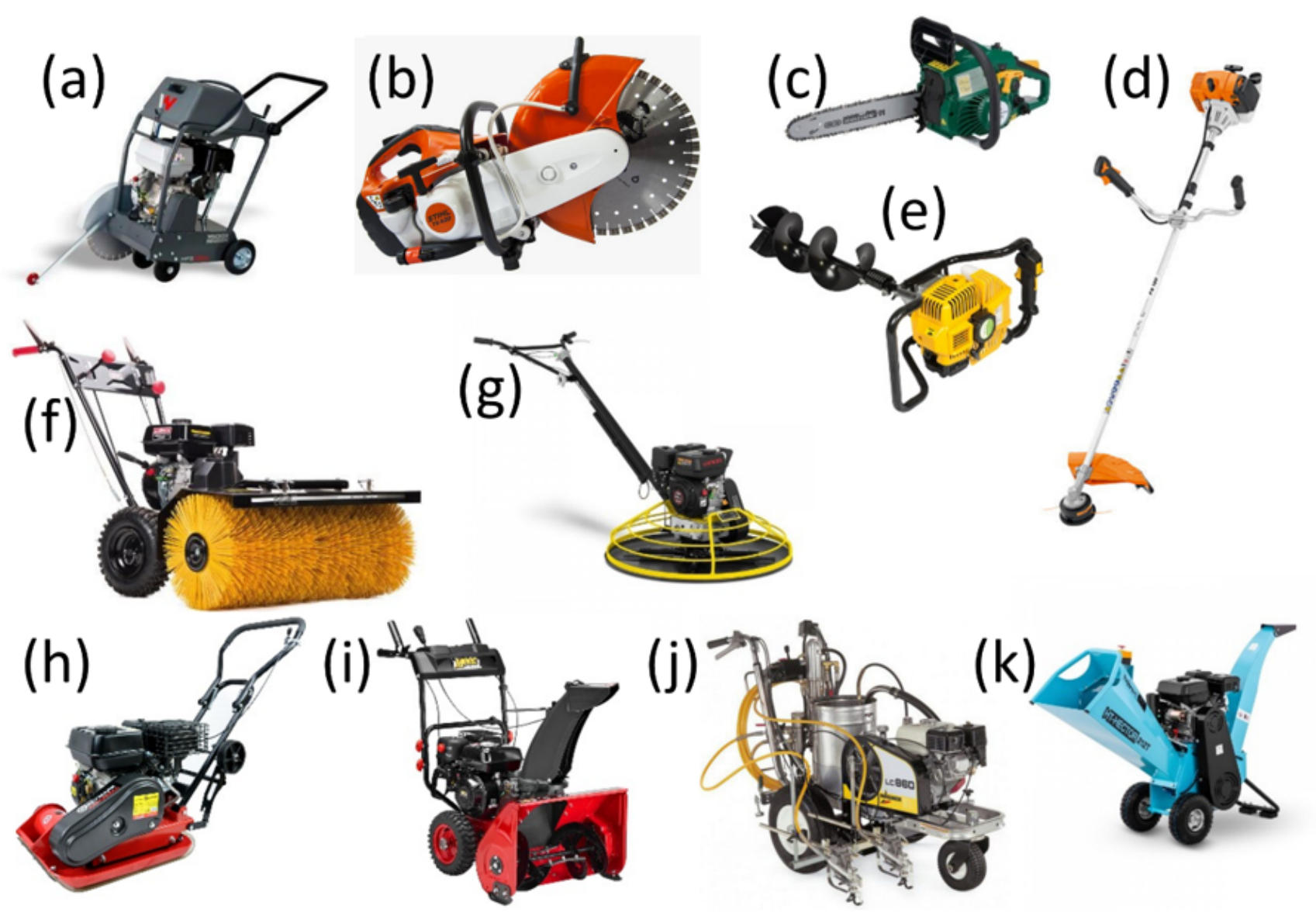

Figure 1

Examples of machinery with small engines used in the construction and maintenance of road infrastructure, where: (a) concrete and asphalt cutter, (b) circular saw, (c) chain saw, (d) combustion scythe, (f) pavement and car park rotary broom, (g) concrete trowel, (e) soil drill, (h) soil compactor, (i) snowblower, (j) road marking machine, (k) wood chipper 


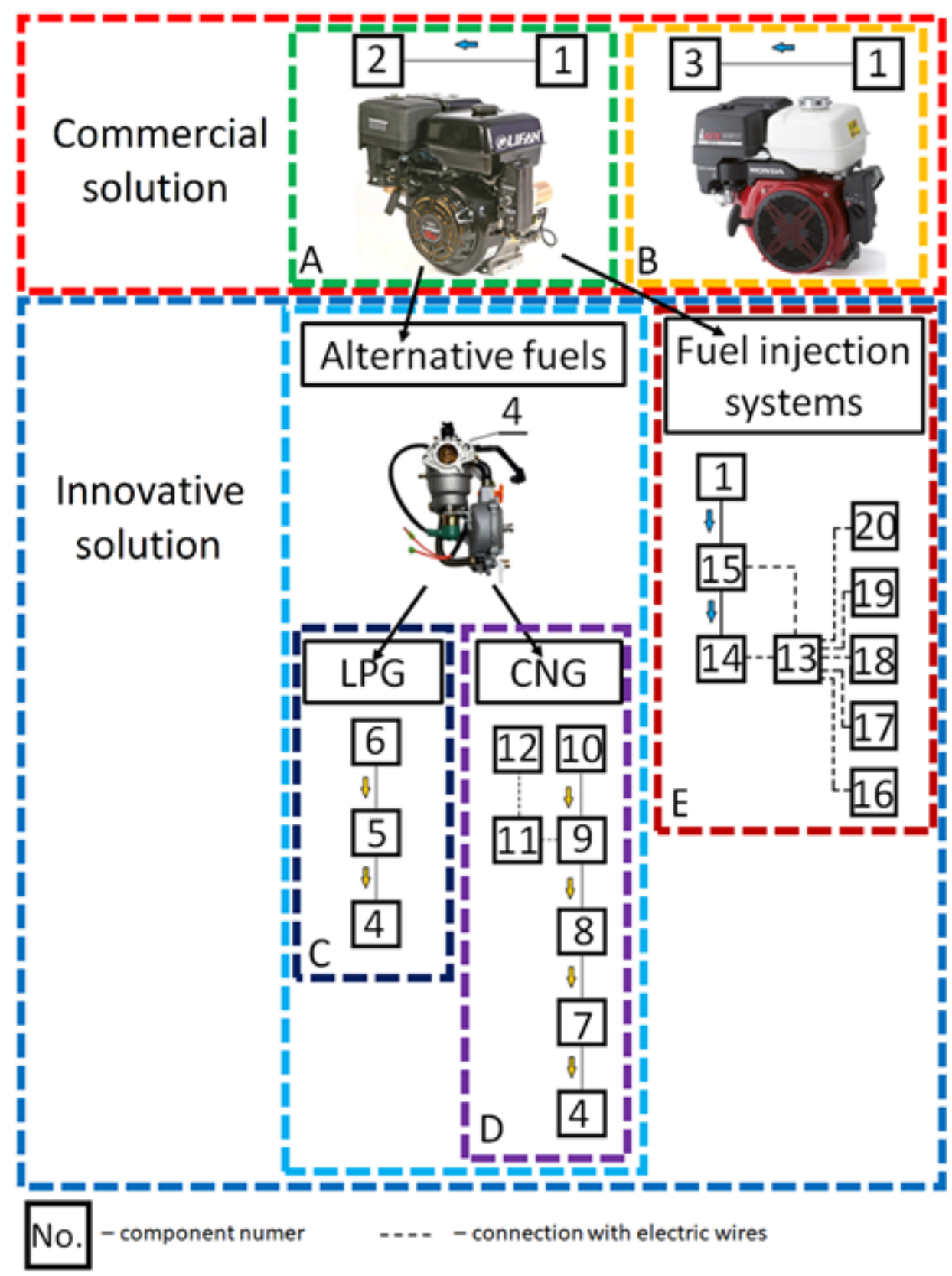

- connection with a hydraulic conduit (gasoline) oraz a pneumatic conduit (LPG or CNG)

$\leftarrow$-gasoline flow direction $\&$-gas (LPG or CNG) flow direction

Figure 2

Tested drive units: commercial engines: A - German GX 390, B - Honda iGX 390; innovative designs: C LPG fuelled engine, D - CNG fuelled engine, $E$ - engine with electronic fuel injection; where numbers on the diagrams represent the basic components of the fuel supply system: 1 - fuel tank, 2 - gasoline carburettor, 3 - gasoline carburettor with electronically controlled flap, 4 - carburettor for gaseous fuels (LPG and CNG), 5 - regulator (from 1.5 MPa to $0.01 \mathrm{MPa}$ ), 6 - low pressure tank ( $1 \mathrm{MPa}$ ), 7 - secondstage regulator (from 0.6 MPa to 0.01 MPa), 8 - first-stage regulator (from $20 \mathrm{MPa}$ to $0.6 \mathrm{MPa}$ ), 9 - gas heater, 10 - high-pressure tank (20 MPa), $11-12 \mathrm{~V}$ battery, 12 - DC converter from $12 \mathrm{~V}$ to $230 \mathrm{VAC}, 13$ - electronic control unit, 14 - injector, 15 - electric fuel pump 16 - wideband sensor of oxygen contents 
in exhaust gases, 17 - intake air temperature sensor, 18 - engine temperature sensor, 19 - engine rotational speed and crankshaft angular position sensor, 20 - throttle position sensor

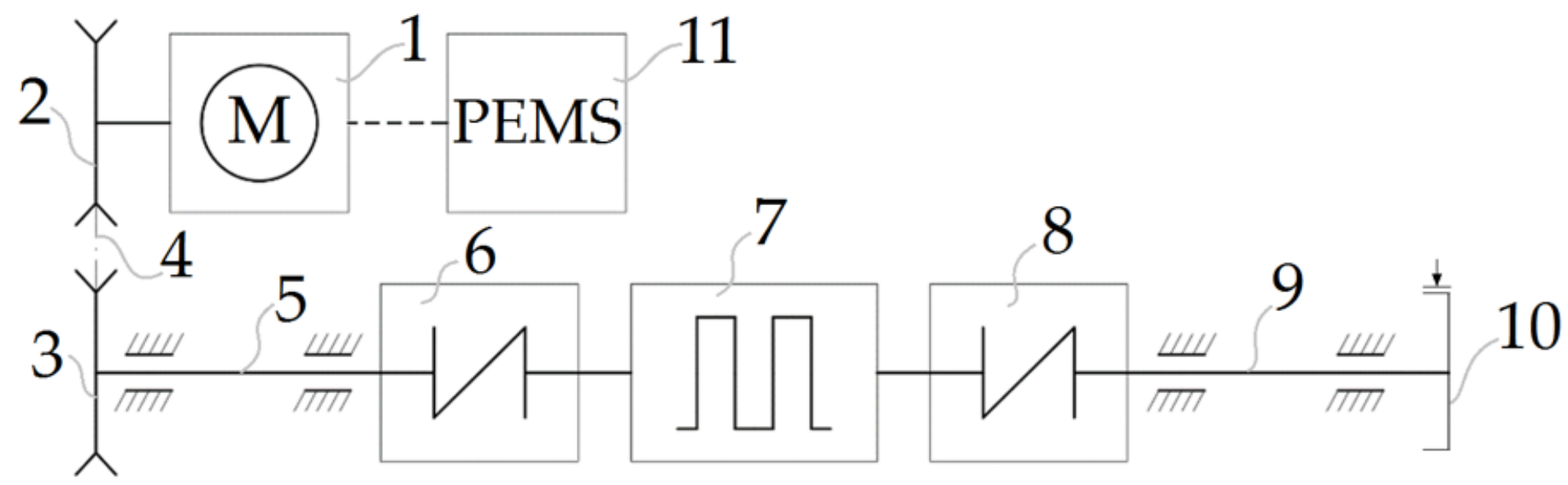

\section{Figure 3}

Diagram of an engine chassis dynamometer for low-power engines, where: 1 - internal combustion engine, 2 - driving pulley, 3 - driven pulley, 4 - belt transmission (ratio 1:1), 5 and 9 - layshaft, 6 and 8 clutch with elastic insert, 7 - torque meter with speed measurement, 10 - brake with control of braking torque value, 11 - PEMS
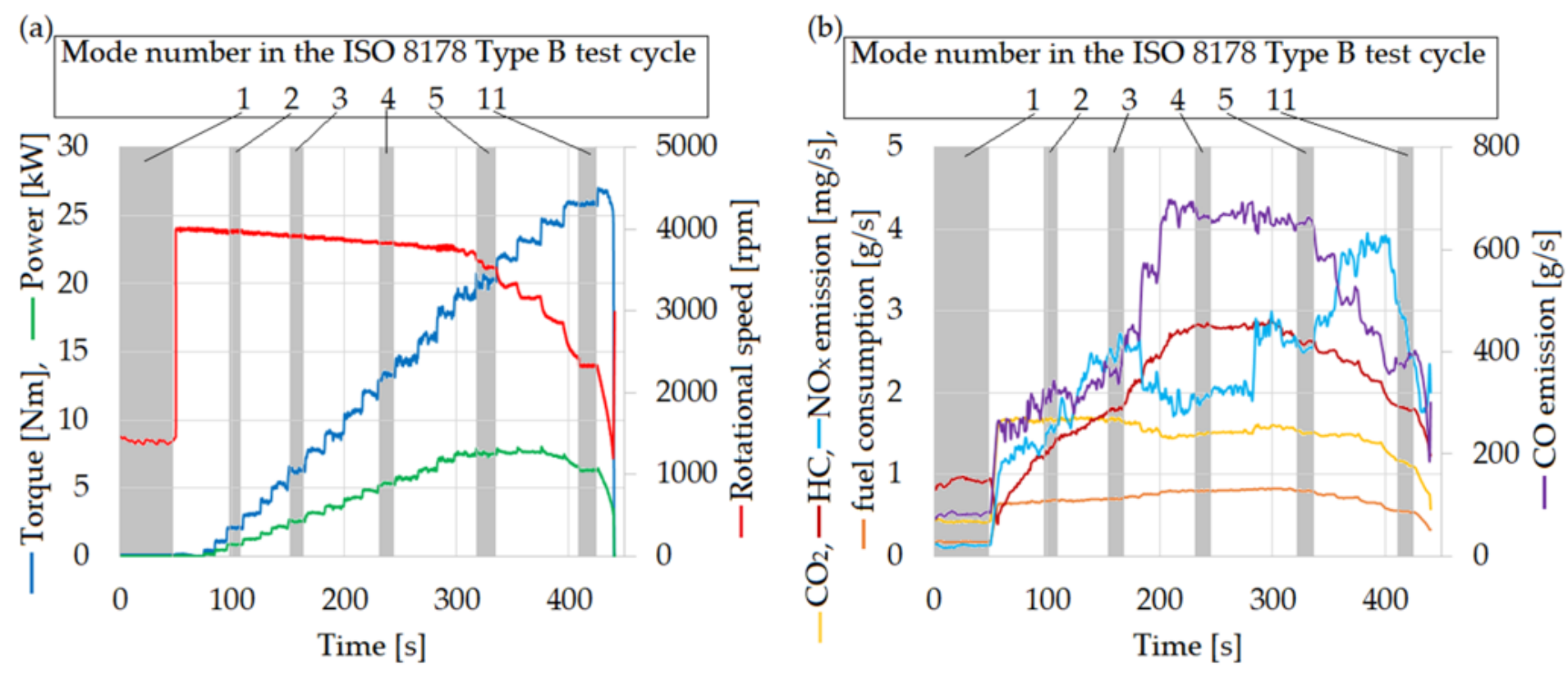

\section{Figure 4}

Characteristics of the Lifan GX 390 internal combustion engine with carburettor power system during testing, where: a) characteristics of power, torque and speed as a function of time and $b$ ) characteristics of $\mathrm{CO}, \mathrm{HC}, \mathrm{NOx}, \mathrm{CO} 2$ exhaust emissions and fuel consumption. 
a) $700 \quad$ b) 9

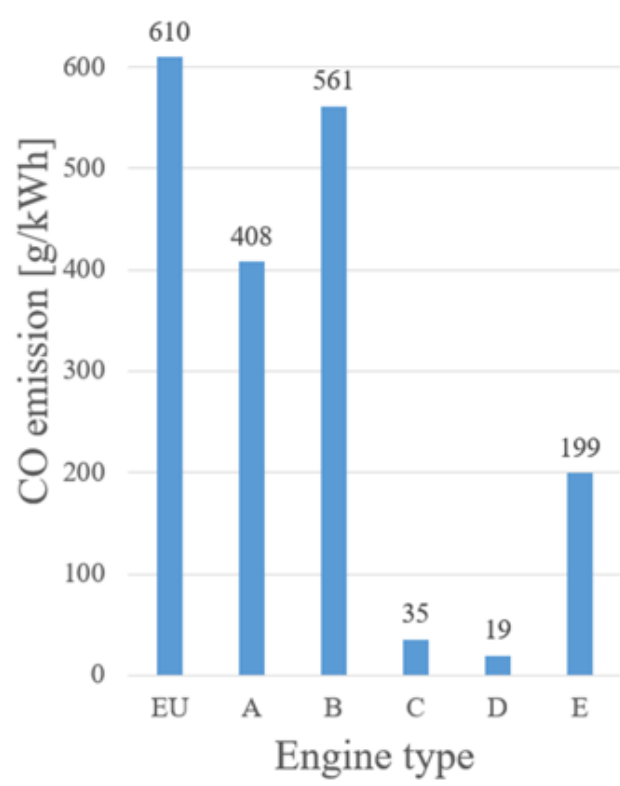

b) 9

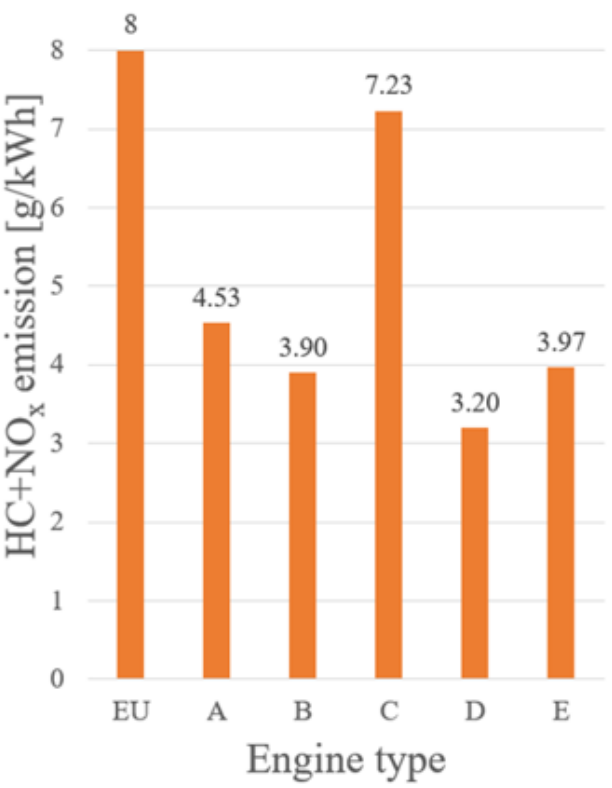

c) 120

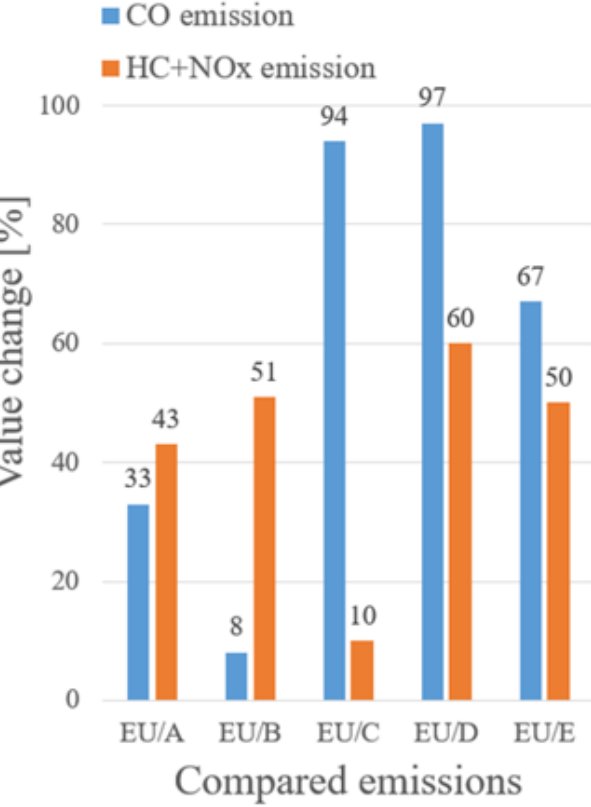

\section{Figure 5}

Emission of $\mathrm{CO}, \mathrm{HC}+\mathrm{NO}$ from small engine related to the emission limits in the European Union, where EU - emission limits allowed in the European Union, commercial engines: A - German GX 390, B - Honda iGX 390; innovative designs: $C$ - engine fuelled by LPG, D - engine fuelled by CNG, $E$ - engine with electronic fuel injection
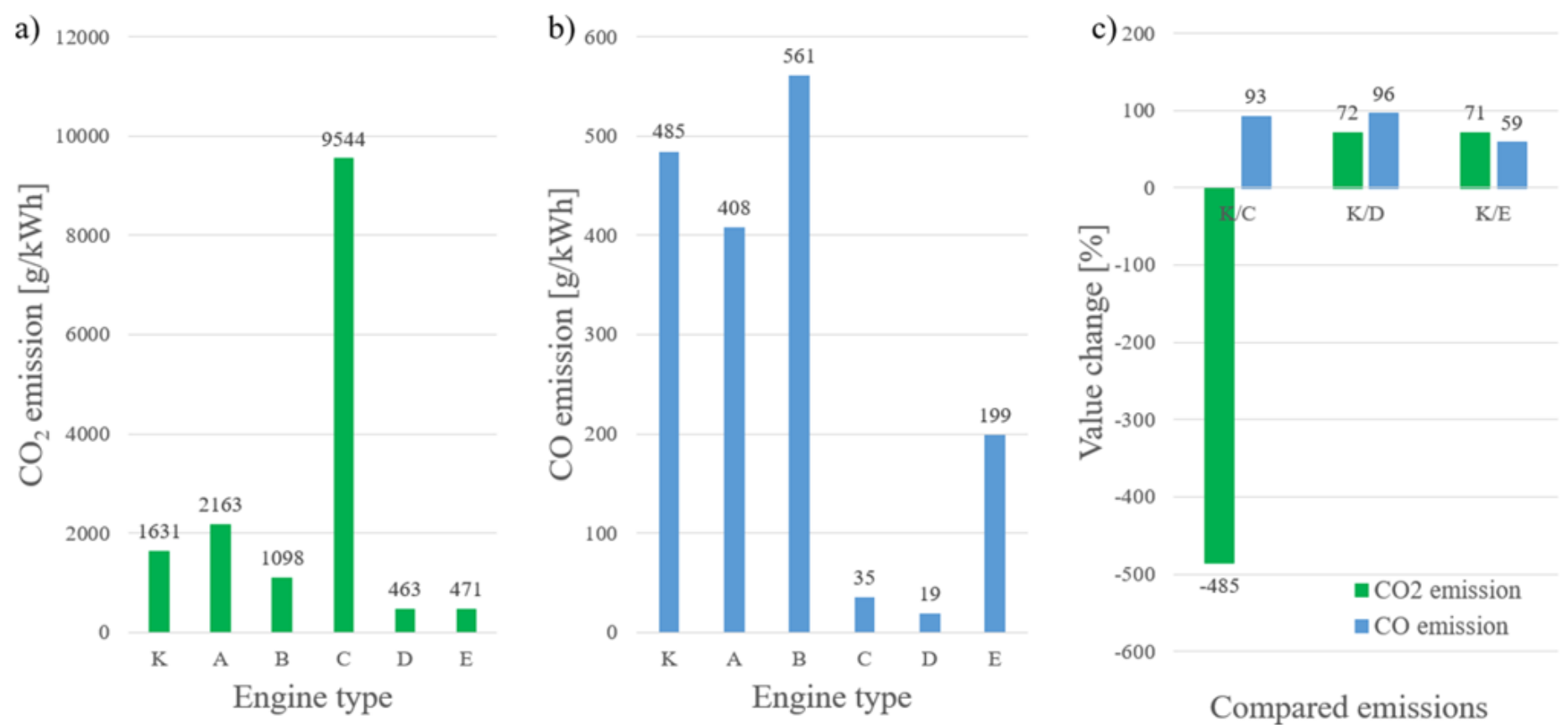

Figure 6 
CO2 emission, $\mathrm{CO}$ from small engine, where $\mathrm{K}$ - is the average emission from commercial engines, commercial engines: A - German GX 390, B - Honda iGX 390; innovative designs: C - engine fuelled by LPG, D - engine fuelled by CNG, E - engine with electronic fuel injection

3

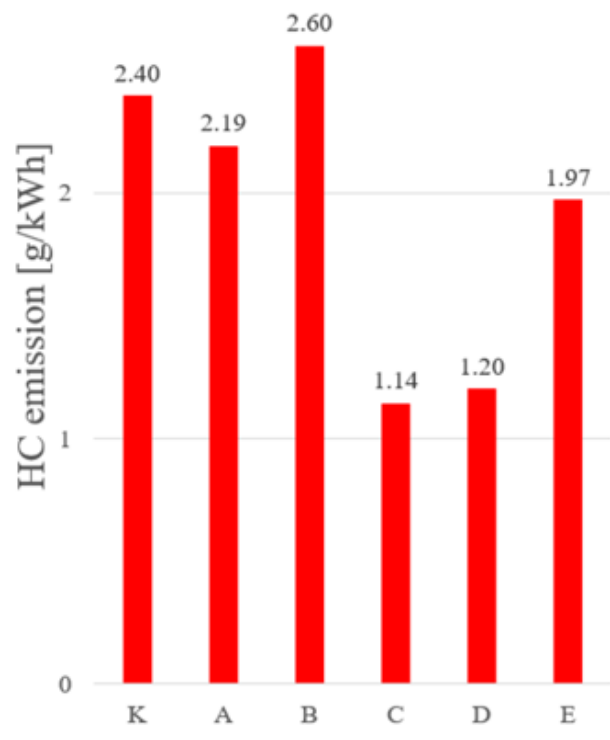

Engine type

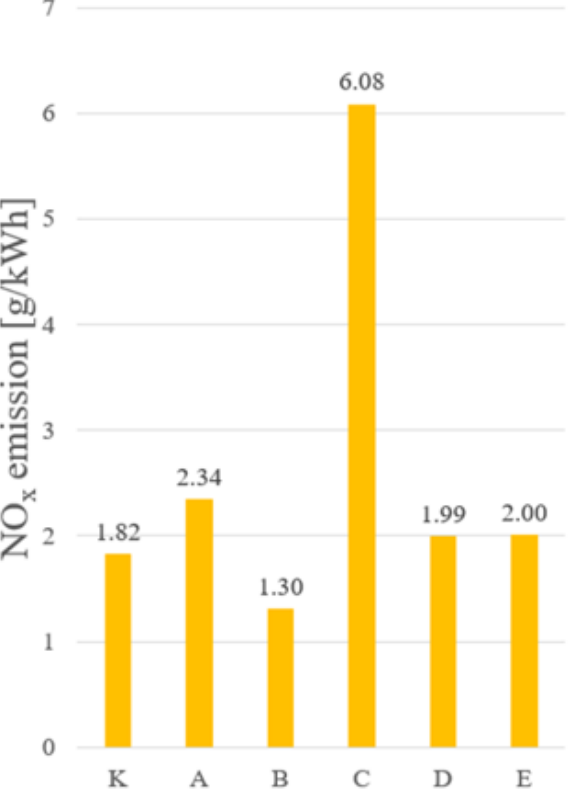

Engine type
100

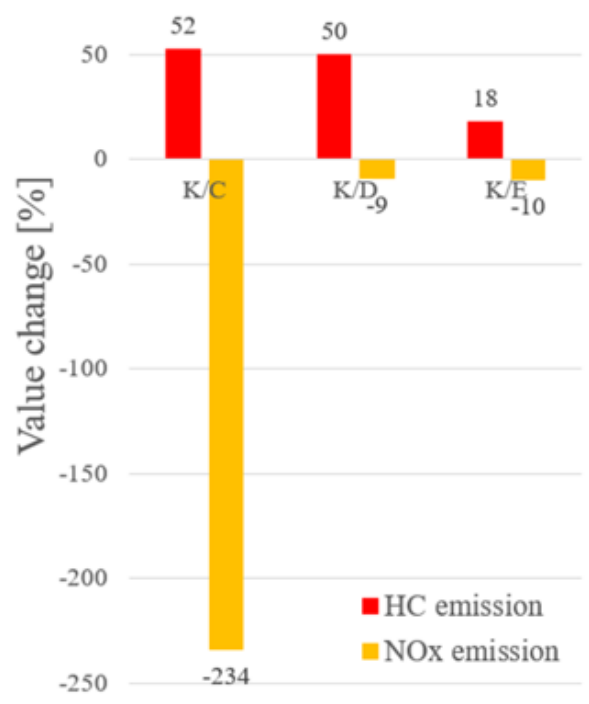

Compared emissions

\section{Figure 7}

$\mathrm{HC}$, NOx emission from small engine, where $\mathrm{K}$ - is the average emission from commercial engines, commercial engines: A - German GX 390, B - Honda iGX 390; innovative designs: C - engine fuelled by $\mathrm{LPG}, \mathrm{D}$ - engine fuelled by CNG, $\mathrm{E}$ - engine with electronic fuel injection

\section{Supplementary Files}

This is a list of supplementary files associated with this preprint. Click to download.

- Appendix.docx 